\title{
Dronedrab og etik - i princippet og i praksis
}

Morten Dige, Afdeling for Filosofi og Idehistorie, Aarhus Universitet

I artiklen argumenteres der for, at de moralske problemer $i$ den militcere praksis med målrettede dronedrab knytter sig til en rakke bestemte karakteristika ved dronekrig, som er definitoriske. Det er derfor problematisk, at der ofte abstraheres fra disse karakteristika, når moralfilosoffer diskuterer, om dronekrig "i princippet" er moralsk forsvarlig eller ej. ${ }^{1}$

Det er en udbredt opfattelse i den moralfilosofiske debat om dronekrig, at brugen af dødbringende ubemandede luftvåben ikke i sig selv er moralsk problematisk, og at vi ikke skal klandre droneteknologien for de umoralske måder, den tilfældigvis anvendes i den virkelige verden. Én ting er, hvordan dronerne bruges $i$ praksis, noget ganske andet er, om de $i$ princippet udgør et moralsk problem. Jeg forholder mig kritisk til denne manøvre og knytter dermed an til det nylige temanummer om "droner og krig" i nærværende tidsskrift (Politik vol. 20, nr. 1).

Min grundlæggende antagelse er, at den virkelige verdens dronedrab ikke er en tilfældig eller kontingent brug af droneteknologien. De afspejler træk ved de militære dronesystemers pragmatik, dvs. den kontekst af formål, intentioner, relationer m.v., som teknologien ikke kan tænkes i abstraktion fra uden, at vi kommer til at tale om droner i en form for drømmeland. Jeg tager udgangspunkt $i$ et eksempel fra nyere international retshistorie, hvor modstillingen mellem principper og praksis blev gjort gældende på en illustrativ måde.

Er atomvåben generelt ulovlige?

I 1996 anmodede FN's generalforsamling om en rådgivende udtalelse fra Den Internationale Domstol (ICJ) om følgende spørgsmål: "Er truslen om eller brugen af atomvåben under nogen omstændigheder tilladt ifølge international ret?” (ICJ 1996). Spørgsmålet

\footnotetext{
${ }^{1}$ Artiklen er en let bearbejdet version af en engelsksproget artikel: Dige, M. 'Drone Killings in Principle and in Practice', Ethical Theory and Moral Practice årg. 20, s. 873-883 (2017), med tilladelse fra Springer Nature, licens nr. 4264730124375.
} 
gjaldt m.a.o. om truslen om eller brugen af atomvåben ud fra retlige principper må betragtes som generelt ulovlig.

Domstolen inddelte spørgsmålet i syv underspørgsmål. Seks af disse var af relativt formel karakter og lod sig afgøre i enstemmighed eller med overvældende majoritet. Sagens principielle kerne blotlagdes i det mere specifikke underspørgsmål om atomvåbens forenelighed med Den Humanitære Folkeret. I forhold til dette spørgsmål var Domstolen delt lige over (7-7), men med formandens stemme som afgørende fandt det tekniske flertal, at

"[...] the threat or use of nuclear weapons would generally be contrary to the rules of international law applicable in armed conflict, and in particular the principles and rules of humanitarian law;

However, in view of the current state of international law, and of the elements of fact at its disposal, the Court cannot conclude definitively whether the threat or use of nuclear weapons would be lawful or unlawful in an extreme circumstance of self-defence, in which the very survival of a State would be at stake" (ICJ 1996, 44).

Afvisningen af at erklære atomvåben principielt ulovlige havde dog i realiteten også opbakning fra et medlem af mindretallet, nemlig Stephen Schwebel fra USA. Han stemte imod den ovenstående formulering, fordi han var af den overbevisning, at visse trusler om og såkaldt "taktiske" brug af atomvåben ville være klart lovlige. Den logiske følge er naturligvis, at retten kunne "conclude definitively whether the [...] use of nuclear weapons would be lawful or unlawful".

Schwebel sondrede i den forbindelse mellem strategisk ("countervalue") og taktisk ("counterforce") brug af atomvåben. Som et (hypotetisk) eksempel på lovlig brug af det sidste hævdede han, at truslen om kemisk krigsførelse fra irakiske styrker i den første Golfkrig kunne retfærdiggøre en trussel om (og ex hypothesi brug af) nuklear gengældelse (Schwebel 1996, 323ff).

Schwebel bemærkede, at atomvåben udgør "en titanisk spænding mellem statslig praksis og retlige principper". Hvis han med "statslig praksis" henviste til den historiske brug af atomvåben, er hans pointe indlysende korrekt, men for Schwebel er løsningen på den titaniske spænding ikke at bringe den statslige praksis i overensstemmelse med de retlige principper ved at ulovliggøre atomvåben. Hans centrale påstand er, at der ikke $i$ princippet er noget ulovligt ved brug af atomvåben. Man kan forestille sig brug af atomvåben som ikke gør vold på krigens love. Man kan f.eks. forestille sig en rent defensiv dybvandsatombombe brugt mod en aggressiv ubåd bevæbnet med atommissiler. I et sådant scenario er det tænkeligt, at det kun er lovlige mål, der bliver dræbt og at de typiske proportionalitetsproblemer grundet langsigtet kontaminering m.v. ville være væsentligt reduceret. Eller man kunne forestille sig et stort antal fjendtlige tropper isoleret midt i en ørken, men i besiddelse af langtrækkende angrebsvåben. At udslette dem alle med et "tak- 
tisk" (eller ligefrem "kirurgisk") atomvåben, ville ikke nødvendigvis være disproportionalt. Retlige principper bør ideelt tage højde for alle tænkelige scenarier og ikke fx ulovliggøre noget, som rent faktisk ville være tilladt ifølge krigens love og international ret $i$ almindelighed. Schwebel var af den opfattelse, at det ville være at fejle til den sikre side at holde en dør på klem for atomar afskrækkelse og gengældelse.

Sådanne overvejelser bringer imidlertid ikke blot statslig praksis og retlige principper i en titanisk spænding. Problemet er, at de snarere fjerner dem så langt fra hinanden, at de mister deres gensidige relevans. Og det åbner for den mulighed, at vi tager ensidigt parti for den ene side. Med Schwebels formulering:

"One way of surmounting the antinomy between practice and principle would be to put aside practice. That is what those who maintain that the threat or use of nuclear weapons is unlawful in all circumstances do. Another way is to put aside principle, to maintain that the principles of international humanitarian law do not govern nuclear weapons" [således som domstolens flertal hævdede]. (Schwebel 1996, 311)

Schwebel fandt begge alternativer uholdbare, fordi han mente, at visse (imaginære) brug af atomvåben ville være i klar overensstemmelse med den humanitære folkeret. Ikke alene udelukker denne ikke atomvåben per se; retten til nationalt selvforsvar leverer i princippet en positiv retfærdiggørelse.

Denne artikels hovedtese er, at der må findes et bredt felt af overvejelser imellem de principielle og de praktiske i Schwebels analyse. Det er i mine øjne ikke tilfældigt, at de lovlige brug af atomvåben, han forestiller sig, er temmelig fantasifulde. De er netop karakteristiske ved at se bort fra de formål og hensigter, som definerede udviklingen af atomvåben. Er de taktiske og "kirurgiske" våben overhovedet en væsentlig del af atommagternes arsenal? Og hvor meget virkelighedsforankring har ideen om atomvåben uden vidtgående og langvarige ødelæggelser? Og endelig: givet at den slags "kirurgiske" våben eksisterer eller kunne udvikles, er det så troværdigt, at de er den eneste måde at afværge de imaginære trusler på? Er der fx nogen tænkelige scenarier, hvor den eneste måde at standse en ubåd er at atombombe den?

Mit forslag er at kalde den slags overvejelser pragmatiske. I sprogvidenskaben handler pragmatik om betydningen af et sprogligt udsagns kontekst f.eks. i form af sprogbrugernes relationer og intentioner. På analog vis kan vi sige, at en teknologis pragmatik forsyner os med dens kontekst i form af bl.a.:

- Teknologiens konkrete funktionsmåde

- Intentionerne bag teknologiens udvikling

- Teknologiens sociale og politiske oprindelse

- Teknologiens indbyggede formål

- Relationerne mellem dem, der hhv. udnytter og påvirkes af teknologien. 
Pragmatiske overvejelser bevæger sig således fra det "taktiske" niveau af en teknologis konkrete anvendelse til det "strategiske" niveau, som inddrager de overordnede mål og strategier, der konstituerer teknologiers og våbensystemers design og dermed bestemmer deres realistiske anvendelser. Jeg vil i det følgende vise, at optimistiske argumenter for at dronedrab "i princippet" indebærer et moralsk fremskridt er af begrænset relevans i den virkelige verden, fordi deres langt mere problematiske brug i praksis ikke skyldes tilfældigheder.

\section{Principper og praksis for dronedrab}

I introduktionen til en antologi om drab via fjernbetjening finder vi en forbilledlig klar formulering af Schwebels synspunkt overført til dronekrig:

"I believe it is the failure to differentiate drone use in principle and drone use in practice that is the cause of so much of the current confusion in the present debate. [...] Whether a given technology is being justly used in the real world is, of course, a critically important question for scholars to analyze and debate. But it is, to be sure, a separate question from moral issues intrinsic to technology that can be analyzed regardless of present context" (Strawser 2013, 8).

Også her er der en række grunde til at være skeptisk. Strawser forsøger at give det indtryk, at kontroversielle eller klart umoralske militære dronepraksisser er en form for dual useproblem. Det kan måske umiddelbart virke plausibelt nok: Det er velkendt, at teknologier kan anvendes på måder, der er problematiske (moralsk eller på anden vis) som et resultat af faktorer, der er rent ekstrinsiske, dvs. ikke knyttet til teknologien som sådan og stik imod hensigterne hos de ingeniører, der udviklede den. Vi kan f.eks. tænke på søm og skruer som, ud over deres tilsigtede brug, kan hældes i hjemmelavede granater og omdannes til midler til lemlæstelse og drab. Vi har været chokerede vidner til hvordan et passagerfly eller en bus kan gøres til terrorvåben. Men det er en fejl at kaste skylden på søm eller busser og forsøge at forbyde dem, fordi de kan blive misbrugt på denne vis.

Min påstand er, at militære droner ikke falder i samme kategori. Her er sagen ikke, at de er designet til helt andre formål end dem, de anvendes til i praksis. Jeg vil argumentere for at netop det modsatte er tilfældet. I et berømt citat gjorde den romerske statsmand og filosof Seneca gældende, at "et sværd ikke dræber nogen, men [blot] er en drabsmands våben" (Senecas moralske breve, nr. 87). Men det er jo en åbenlys forsimpling. At et sværd bliver brugt til at dræbe med er ikke overraskende, eftersom det er sværdets tilsigtede brug, det formål det er designet til. Den dødelige brug er ikke alene et resultat af faktorer, som er ekstrinsiske for sværdteknologien. Den nyere udgave "Guns don't kill 
people; it's people who kill people" bliver trættende at høre på, hvis det er et militært angrebsvåben, der er tale om.

Strawser og mange andre (bl.a. Arkin 2010; Hallgarth 2013; Whetham 2015; Buchanan $\&$ Keohane 2015) synes at anse droner for at befinde sig et sted midt imellem. Droner er som atomenergi, som kan bruges til aggressive terrorbombninger på den ene side og til strålekanoner i kræftbehandling på den anden. At bruge atomenergi til de umoralske formål er således ikke et essentielt træk ved teknologien. Selv om den oprindelig blev udviklet $\mathrm{i}$ en terroristisk strategi for bombning af civile, så er der ikke noget galt med teknologien per se eller "i princippet".

Det argument får imidlertid kun luft under vingerne, fordi teknologien bliver defineret i så tilpas brede termer, at den kan åbne for en bred vifte af anvendelser. Men det vi taler om her, er militcere droner, som er instrumenter på et langt senere stadium af specifik produktudvikling og design end atomenergi. De er udviklet i en pragmatisk kontekst med højst specifikke strategier og angrebsmål for øje. Den militære drone er derfor atombomben snarere end strålekanonen. Den bærer en række iboende eller definitoriske egenskaber med sig, som må inddrages i vore refleksioner over dronedrab. Hvis vore refleksioner over dronedrab "i princippet" foretages i abstraktion fra sådanne definitoriske træk, slipper militære droner for let af den moralske krog. Jeg vil således i de følgende afsnit forsøge at udpege nogle af de definitoriske træk ved dronedrab, som nødvendigvis må inddrages i vor moralske bedømmelse af disse.

\section{Droner og ekstrem asymmetri}

Droner er ineffektive våben over for fjender med nogenlunde symmetrisk luftforsvar. De er således designet til konflikter kendetegnet ved ekstrem asymmetri. I lyset af at fjenden i en række af vore igangværende konflikter er terrorister er det selvsagt fristende at anse det som en fordel at være i noget nær total kontrol. Men som vi skal se, bringer det os ind $i$ et ganske andet territorium, hvad angår international ret. Det skyldes, at konflikter kan nå en grad af asymmetri, hvor de ikke længere lader sig forstå hverken som krig eller som selvforsvarshandlinger. Rent formelt er de militære operationer i Pakistan og Yemen ikke krigshandlinger, da der ikke foreligger en krigserklæring og krigshandlingerne ikke er rettet mod de nationer, de udspiller sig i. Droneangrebene falder derfor snarere ind under de ikke-statslige væbnede konflikter, som er reguleret af Genevekonventionens Artikel 3, men det rejser nye paradokser, som jeg vender tilbage til i næste afsnit.

Henriksen og Ringsmose peger i et nyligt nummer af Politik på at der eksisterer "en oplevet grænse for, hvor asymmetrisk krigen må være" (Henriksen \& Ringsmose $2017,13)$. Som vi skal se, hænger dette formodentlig sammen med at retfærdiggørelse af krig forudsætter en omfattende og relativt akut trussel. Hvis sagen er, at vi har noget nær "frit slag" over for fjenden, svækkes relevansen af den type af retfærdiggørelse. Droneangreb uden en akut trussel og uden en reel risiko for modangreb får på et tidspunkt mere 
form af en form for udslettelsesprogram, hvor vore fjender, med Uwe Steinhofs prægnante formulering, bliver behandlet som "cockroaches on the receiving side of pest control" (Steinhoff 2013, 207).

Tilsvarende vil det formentlig ikke komme på tale at udføre droneoperationer i områder behersket af regimer med nogenlunde symmetrisk politisk magt og indflydelse. Det er i det lys ikke en tilfældighed, at droner primært anvendes i lande som Pakistan og Yemen. Man kan prøve at forestille sig følgerne af en fremmed magts målrettede dronedrab på en formodet terrorist i Bruxelles (hvor der synes at befinde sig nogle stykker). Den belgiske stats og EU's noget mere symmetriske magt gør et sådant scenario højst usandsynligt (kunne man håbe). Den nuværende dronebaserede strategi sigter mod massiv eller noget nær total overvågning af og kontrol over territorier, som - formelt set - er under fremmede staters suveræne herredømme. Det er ikke svært at forestille sig de destabiliserende virkninger af dette.

Dertil udgør de omfattende sociale, kulturelle of psykologiske indvirkninger på den civile befolkning nye former for asymmetri. Dette er bl.a. beskrevet i rapporten "Living under Drones" udarbejdet af forskergrupper fra Stanford og New York University (International Human Rights and Conflict Resolution Clinic 2012). Befolkninger i fjerne egne af Pakistan og Yemen lever de facto på en fremmed magts nåde, vel at mærke en magt, som de ikke har nogen indflydelse på, endsige demokratisk kontrol med. Det forekommer mig ikke helt ved siden af, når Steinhoff bemærker, at en sådan behandling kunne "remind those on the receiving side of such technology all too much of times allegedly past, where the self-proclaimed Herrenmenschen and the harbingers of civilization discipline the brutes, mostly by killing them" (Steinhoff, ibid.).

\section{Droner og aggression}

Militære droner er designet til aggressive snarere end defensive formål. Kombinationen af de overvågende og "kirurgisk" dødelige funktioner viser, at droner er designet til målrettede drab på personer, som har være under dronebaseret overvågning igennem længere tid. Dette medfører en signifikant udvidelse af det 'vindue' (window of opportunity), i hvilket man kan skride til forebyggende angreb. Ganske forudsigeligt har en række teoretikere gjort gældende, at målrettede drab kan betragtes som en udvidet form for selvforsvar eller beskyttelse af civile (se f.eks. McMahan 2012). De såkaldte High Value Targets (HVT) fremstilles typisk som personer, der er konstant involveret i at planlægge eller udføre terroraktioner. Terrorister, der dræbes i droneangreb anses således for at udgøre en latent, uundgåelig trussel i kraft af deres blotte eksistens. At dræbe dem når og hvor, der er lejlighed til det, er ud fra den betragtning retfærdiggjort som en nødvendig forsvarshandling.

Frem for alt er dette i modstrid med hovedstrømmen i international retstænkning og etik, hvor man insisterer på, at forebyggende angreb vitterlig er et angreb, dvs. en 
aggressiv handling. ${ }^{2}$ Her er det vigtigt at gøre sig klart, at de fleste af USA's dronedrab ikke finder sted i en regulær væbnet konflikt, hvilket betyder, at de dræbte terrorister ikke kan betragtes som fjendtlige kombattanter. Frem for at forstå dronedrab som krigshandlinger, kunne man i stedet forstå dem som selvforsvar mod organiserede kriminelle. Det synes at have været den foretrukne strategi under Obama-regeringen (Brooks 2014). Problemet er, at sådanne selvforsvars-operationer er underlagt langt stærkere begrænsninger end drab i krig, hvad angår nødvendighed (truslens umiddelbarhed og fraværet af alternativer til drab), proportionalitet, formodning om uskyld og beviser for skyld hævet over rimelig tvivl (Blank 2012, 1668; McMahan 2012, 147). Modsat krig, kommer drab i selvforsvar kun på tale som en sidste udvej og vi accepterer almindeligvis ikke, at sagesløse tilskuere bliver dræbt som følgeskade (collateral damage) i forbindelse med uskadeliggørelse af forbrydere. I takt med at retfærdiggørelse med henvisning til selvforsvar udvides til ikke-akutte situationer bør proportionalitetskravet styrkes tilsvarende. Men sagen er, at droneoperationer ikke kan gennemføres under et sådant styrket krav, givet den virkelige verdens epistemiske begrænsninger: vi ved ikke nok om hvem, der må betragtes som sagesløse tilskuere eller hvor de befinder sig hvornår i fjerne egne af Pakistan eller Yemen.

Derudover synes kriterierne for at komme på listen over HVT (Det Hvide Hus' dødsliste) i højere grad at angå terrorangreb og terrorplaner i fortiden end håndfaste beviser for aktuelle planer. Dermed bliver det tvivlsomt om de målrettede drab i det hele taget kvalificerer som selvforsvar eller beskyttelse af civile snarere end en dødsstraf som burde underlægges endnu mere krævende kriterier end drab i selvforsvar. Genevekonventionens artikel 3 angående ikke-statslige væbnede konflikter forbyder eksplicit henrettelser uden forudgående afgørelse fra en "behørigt konstitueret domstol." Der kan næppe herske tvivl om at de instanser, der træffer afgørelse om dronedrab, falder uden for denne kategori.

Jeff McMahan har berettet, at de fleste mennesker fandt hans begrundelse af drabet på Osama Bin Laden som en selvforsvarshandling "overraskende" (McMahan 2012). De opfattede det snarere som en henrettelse. Sagen er så blot, at det var en henrettelse uden rettergang og efter kriterier som i bedste fald er uklare (Kretzmer 2005, 176). Grégoire Chamayou stiller dilemmaet forbilledligt klart op i bogen Drone Theory:

"To sum up, the only two possibilities turned out to be unworkable: either (1) the strikes were a law enforcement activity, in which case they ought to conform to the restrictions that applied to them, one of which called for the gradation in the use of force - something that was impossible for the drone - or (2) they were covered by the laws of war, although these laws do not apply in zones that are currently

\footnotetext{
${ }^{2}$ I den engelsksprogede debat sondres mellem angreb som pre-emptive eller preventive. De førstnæunte er svar på en med sikkerhed fastslået og umiddelbart forestående trussel, som ikke kan afværges på anden vis. Sidstnævnte er en mere opportunistisk strategi, der typisk er drevet af et ønske om at udnytte en aktuel styrkemæssig overlegenhed.
} 
not experiencing armed conflict, such as Pakistan or Yemen, where they nonetheless operate at present." (Chamayou 2015,171).

Særligt tvivlsom er den udbredte brug af såkaldte "signatory strikes" baseret på "livsmønster-analyser”. En højtstående amerikansk regeringsembedsmand har for nylig beskrevet udpegningen af mål som en proces, der involverer:

"[A] variety of signatures, from the information and intelligence that in some ways is unique to the US government, for example [...] to the extent an individual's activities are analogous to those traditionally performed by a military (min fremh.)" (Ackerman 2016).

Det siger sig selv, at sådanne gætterier om et potentielt måls krigeriske eller voldelige natur næppe kvalificerer som strafværdighed hævet over rimelig tvivl. Som Henriksen og Ringsmose påpeger (med reference til Kahn 2002): "Politivirksomhed er med andre ord kendetegnet ved, at individer gøres til genstand for magtanvendelse på grund af det, de har gjort, og ikke hvem de er”. Angreb baseret på gætterier om målets status lever selvsagt heller ikke op til diskriminationsprincippet. Dette fører os til dronestrategiens definitoriske problem vedrørende følgeskader og utilsigtede drab.

\section{Droner og "collaterals"}

Det hævdes ofte, at droner i det mindste potentielt repræsenterer et moralsk fremskridt, fordi de er bedre til at skelne mellem kombattanter og civile end alternative våbensystemer. Men her er det vigtigt at gøre sig klart, hvad de alternative våbensystemer er. Givet at droner er vendt mod oprørere og terrorister i ikke-statslige væbnede konflikter, bør de rimeligvis sammenlignes med alternativer inden for den kontekst. Målrettede dronedrab bør derfor sammenlignes med alternative strategier for terrorbekæmpelse i almindelighed og andre former for målrettede drab i særdeleshed. Et oplagt eksempel er det målrettede drab på Bin Laden som ikke blev udført med droner men af en kommandoenhed, dvs. "boots on the ground". Det er derfor vildledende, når Strawser bemærker, at droner "for all their current and potential misuse, have the potential for tremendous moral improvement over the aerial bombardments of earlier eras" (Strawser 2012). Det siger sig selv, at hvis sammenligningen går på luftbombardementer, fx af de store tyske byer under Anden Verdenskrig, så falder den ud til fordel for stort set alle andre kendte våbensystemer, hvad angår efterlevelsen af principperne om diskrimination og proportionalitet. Men alternativet til droneangreb i konteksten af oprørsbekæmpelse og asymmetriske konflikter er ikke luftbombardementer. Ingen ædruelig person ville vel have foreslået at bombe hele den landsby, som var Bin Ladens formodede opholdssted? 
Hvorvidt droneangreb medfører en "acceptabel" andel af civile tab afhænger også af, hvordan disse defineres. Som nævnt ovenfor, betaler civile en høj pris alene ved "at leve under droner". Vedvarende at have dræbende droner hængende over hovedet indebærer en form for terror, som rammer fjendtlige terrorister og uskyldige civile i flæng (se Boyle 2015, 115-17; Braun \& Brunstetter 2013).

Avery Plaw har i lighed med Strawser hævdet, at andelen af civile dødsfald som følge af droneangreb er væsentligt lavere end andelen af civile ofre for angreb fra "regeringsfjendtlige elementer" (Antigovernment Elements eller AGE) i Afghanistan (Plaw 2013). Men igen er det forhåbentlig ikke en relevant sammenligning, eftersom terrororganisationer per definition forfølger deres mål ved at angribe civile. Det skal dog retfærdigvis siges, at Plaw ser ud til primært at inddrage antallet af civile ofre for AGE for at pege på, hvor mange der potentielt kunne reddes, hvis droneangreb svækker deres kapacitet til at terrorisere og dræbe civile i væsentlig grad.

Men her har vi endnu et "i princippet"-argument, for der er stærk grund til at betvivle, at drabet på de 40-70 "højt prioriterede mål" (High Value Targets) i årene 20042011, som Plaw rapporterer om, har svækket AGE's kapaciteter i væsentlig grad. Førende eksperter i oprørsbekæmpelse har gjort gældende, at det praktiske resultat af droneangrebene meget vel kan have været det modsatte (Kilkullen \& Exum 2009; Matulich 2012). Blandt plausible forklaringer på dette kunne man for det første nævne, at droneangrebenes forstærkede asymmetri efterlader AGE med tre alternativer, nemlig 1) overgivelse, 2) at rette angrebene mod fjendens "civile kombattanter" (dvs. droneoperatørerne) eller 3) rette angrebene mod lokale civile, der anses for at være fjendtlige over for terroristernes sag. Qua deres status som uretmæssige kombattanter burde de i princippet beslutte sig for 1), men sådan fungerer den virkelige verden jo sjældent. Her er det forventelige resultat snarere 3), med mindre vi har held med at rykke ondet op med rode ved at dræbe højt prioriterede mål i hurtigere takt end nye afløsere kan rekrutteres. Et sådant udfald kan være svært at garantere. En anden plausibel forklaring er selvfølgelig, at civile ofre for og vidner til droneangreb ikke baserer deres reaktioner på sofistikerede proportionalitetskalkuler. De er typisk ikke optaget af om de indgår i en andel på 3,86\% eller 23,85\%, som er det spektrum, der dækkes af fire forskellige databaser, som rapporterer om droneangreb $i$ Pakistan (Plaw 2013, 138f). ${ }^{3}$ Deres reaktioner baserer sig formentlig i højere grad på en oplevelse af ringeagt for civile liv fra droneoperatørernes side, noget som kunne føre dem til den (utvivlsomt naive) konklusion, at de finder bedre beskyttelse ved at støtte eller i det mindste ikke modarbejde deres lokale krigsherrer.

\section{Droner og hemmeligholdelse}

At pålidelige data om civile tab er vanskelige at fremskaffe er heller ikke nødvendigvis

\footnotetext{
${ }^{3}$ Bredden af dette spektrum (en faktor 6) er i sig selv grund til skepsis over for selvsikre påstande om dronernes overlegne præcision i sondringen mellem kombattanter og civile. Man kan således kun håbe, at dronerne er mere præcise end deres fortalere.
} 
nogen tilfældighed. Dronedrab gennemføres i en dobbelt afsondring fra offentlig granskning. Dronestrategien er for det første ledsaget af et dogme om ikke at tillade terrorister nogen fristeder. Derfor gennemføres dronedrab typisk i fjerntliggende egne og deres radikale uforudsigelighed i tid og sted ("hvor som helst, når som helst") er endnu engang definitorisk. Også i kraft af dette aspekt falder dronestrategien uden for den normale forestilling om krig, som indebærer en afgrænsning i rum (en nogenlunde velafgrænset kampzone) og tid (en formel krigserklæring som begyndelse og en formel fredsslutning som afslutning).

Når ting går galt, som de uvægerligt gør i væbnede konflikter, bliver vi afhængige af informationer fra dronernes overvågningsudstyr, som, trods deres avancerede teknologi ikke giver os det fulde billede: "Drone technology without ground support leaves few options for post-operatic investigations. Further, verifying the combatant status of casualties is mostly impossible" (Rosén 2013, 12)

Afsondringen fra landtropper eller andre potentielle vidner gør det "significantly easier for governments to avoid public scrutiny of their military adventures" (Sparrow 2009, 27). Kendsgerninger om ofrenes reelle status kan være særdeles vanskelige at fastslå alene på basis af overvågningsbilleder og -videoer. Men når sikker identifikation har været mulig, er der en del konkrete eksempler på overdrevne påstande om drab på "højt profilerede" mål, som viste sig ikke at være så højt placerede, når det kom til stykket eller sågar nogle helt andre personer end de postulerede (Boyle 2015; Mayer 2015).

Man kunne forestille sig, at tendensen til at overdrive målenes status hænger sammen med droneoperatørernes fysiske isolation. Strawser ser det som en attraktion ved drab per fjernkontrol, at man kan udskyde effektueringen og bringe flere mennesker ind i kontrolrummet, når der skal træffes vanskelige eller kontroversielle beslutninger og på den måde sikre ekstra kontrol og opsyn med operationerne (Carrol 2012). Men det er oplagt, at det må afhænge en del af, hvem man bringer ind i rummet. Under normale omstændigheder forudsætter vi, at kontrolinstanser har en vis uafhængighed i forhold til de kontrollerede. Hvis situationen i stedet er præget af afsondring og hemmeligholdelse, risikerer man snarere en farlig form for gruppetænkning, som øger risikoen for umoralske beslutninger. Der var mange mennesker til stede i rummet, da beslutningen om "den endelige løsning” på jødespørgsmålet blev truffet, men det gjorde selvsagt ikke beslutningen mindre umoralsk.

Tilmed bliver dronedrab ofte beordret og udført af efterretningstjenester, som per definition ikke er ivrige efter et højt niveau af gennemsigtighed. Det er i det lys, retsfilosoffen Jeremy Waldron minder os om, "how reluctant we should be to deploy principles authorizing homicide in an environment from which we know legal process will be largely banished" (Waldron 2012, 122f). Der er således en diskrepans eller et paradoks involveret i dronernes avancerede overvågnings- og dokumentationskapacitet på den ene side og operationernes hemmeligholdelse og uigennemtrængelighed på den anden.

Det er derfor i bedste fald en halv sandhed at hævde, at "we move pixel by pixel towards ultra high definition and total transparency" (Rosén 2013, 17). At tage et højopløst billede af en kompleks situation gør ikke nødvendigvis situationen mindre kompleks. 
Med "i bedste fald" sigtes der til, at teknologien åbner for militære operationer i konfliktzoner, som tidligere blev anset for at være for afsides og for komplekse. Snarere end at løfte "the fog of war" efterlades vi i "the twin fogs of war and official secrecy" (Ackerman 2016).

Misforholdet mellem operationel og demokratisk transparens er ganske vist næppe ny i krigens historie. ${ }^{4}$ Citatet "i krig er sandheden det første offer" har trods alt 2600 år på bagen. Man kan desuden betvivle, om militære dronestrategier nødvendigvis vil være omgærdet af hemmeligholdelse og uigennemsigtighed, eller om det alene er et kontingent træk ved de nuværende strategier. Jeg mener dog, at pragmatiske overvejelser giver anledning til at anse dronekrig som særligt problematisk i disse henseender. Dronedrab er intimt kædet sammen med et sikkerhedsparadigme, som har domineret de førende militærmagter i et godt stykke tid, et paradigme, hvor hemmeligholdelse, mangel på gennemsigtighed, og intenst politisk spin (om ikke regulær propaganda) vitterligt har været definitorisk. Jeg ser ingen tegn på en grundlæggende ændring af dette i nær fremtid.

\section{Droner og "kombattanters immunitet"}

Et væsentligt sigte med brugen af militære droner er en radikal forøgelse af "vore" (antageligt retfærdige) kombattanters sikkerhed. Strawser argumenterer for, at dette ikke blot er moralsk forsvarligt, men moralsk påkrcevet ifølge hans eget "princip om unødvendig risiko":

"It is wrong to command someone to take an unnecessary potentially lethal risk in an effort to carry out a just action for some good; any potentially lethal risk incurred must be justified by some strong countervailing reason" (Strawser 2013, 344; se også Strawser 2010).

Men det princip er formuleret så vagt, at det er af begrænset relevans i den virkelige verden. Den virkelige verden er overbefolket af "stærke modvægtsgrunde"! Uwe Steinhof peger på én vigtig type af sådanne grunde:

"[W]hen police officers are ordered to make traffic stops and in that context ask for driver's licenses, for instance, we do not arm them to the teeth and do not put them into heavy body armor. The reason for this is quite simply that the citizens do not want that: they want to be confronted with a recognizable human being, not with a Star Wars storm trooper. If this is already sufficient as regards "countervailing reasons" against the strongest protection, then certainly there will be

\footnotetext{
${ }^{4}$ Tak til en anonym reviewer for at påpege dette.
} 
a lot of countervailing reasons in the case of drones." (Steinhoff 2013, 206)

Hvad kunne analoge modvægtsgrunde være i forhold til kravet om at mindske "vore" soldaters risici ved hjælp af militære droner? Muligvis noget i retning af det følgende: Mennesker i fjerne egne af Pakistan hærget af terrorister og krigsherrer foretrækker at blive "beskyttet" af folk, som gør en alvorlig indsats for først at kommunikere og siden leve op til deres ædle hensigter; folk som bestræber sig på at forhandle betingelser for strategien med dem, der faktisk skal leve under dronerne og med alle de sociale og psykologiske eftervirkninger heraf. Hvis dette ikke er tilfældet, men snarere noget nær det modsatte (operationer baseret på en noget lemfældig definition af "low level militants", en fremmed magt som simpelthen påtvinger den civile befolkning sine strategiske betingelser), så bør man efter min mening ikke blive voldsomt overrasket, hvis rekrutteringen til oprørs- og terrorbevægelser stiger efter hvert droneangreb. At prioritere dronedrab over andre metoder til oprørsbekæmpelse synes at støde "hearts and minds" væk snarere end at hverve dem. Igen er min pointe, at dette ikke er en kontingent, rent praktisk konsekvens af dronestrategien, men et resultat af den asymmetri, distance og afsondrethed, som er indbygget $\mathrm{i}$ dronestrategien.

\section{Policy og implementering}

De fem elementer beskrevet ovenfor (asymmetri, aggression, "collaterals", hemmeligholdelse og kombattanters immunitet) sår alvorlig tvivl om følgende udsagn fra Strawser:

"If one believes that the current US policy of targeted killings is morally objectionable, then it is the policy that should be objected to, not this particular way of implementing it." (Strawser 2012).

Jeg vil selvsagt ikke hævde, at der ikke er plads til forbedring inden for den nugældende amerikanske dronepraksis. Det må man i det mindste håbe, når man får indsigt i nogle af de få detaljerede afdækninger af konkrete dronedrab, som er kommet til offentlighedens kendskab - i øvrigt ikke som følge af en kompromisløs bestræbelse på gennemsigtighed fra CIA's side, men snarere som følge af vedholdende pres fra kritiske journalister (se fx Cloud 2011). Men jeg køber ikke den indbyggede præmis om, at den amerikanske policy om målrettede drab blev formuleret forud for og uafhængigt af muligheden for at føre den ud i livet vedhjælp af droner. Det forekommer langt mere plausibelt, at den amerikanske policy er stærkt influeret af scenarier og drejebøger fra droneproducenternes hånd. ${ }^{5}$ Der

\footnotetext{
${ }^{5}$ En indikation af en sådan form for indflydelse ser man af Strawsers ukritiske gengivelse af producenternes egne rosende beskrivelser af militære droners overlegne præcision og diskriminationsevner.
} 
var ikke et omfattende program for målrettede drab forud for implementeringen af militære droner.

Det er på en måde fristende at argumentere for at retningen går den anden vej: droner definerer eller konstituerer policy ved at være ledsaget af et bestemt script, en færdig drejebog for deres anvendelse. Det ville imidlertid også være en forsimpling. Det siger sig selv, at strategien med målrettede drab også er en reaktion på en ny type trussel fra små grupper af exceptionelt farlige fjender. Sandheden er derfor snarere, at teknologi og policy er gensidigt forbundne på mere kompleks vis. Men det er nok til at sætte spørgsmålstegn ved Strawsers synspunkt, at den militære policy er én ting, hvordan dem implementeres en ganske anden.

Vi kan naturligvis drømme om droner med sandt humanitære formål. For eksempel typer af overvågningsdroner, hvis primære funktion er at advare civile mod terrortrusler i nærheden eller at overvåge og dokumentere overgreb mod civile (Whetham 2015). Men igen: grunden til at det ikke er det, vi ser, er ikke blot, at militære droner tilfældigvis bruges anderledes i praksis. Det skyldes, at det aldrig var deres intenderede anvendelse, og de derfor ikke blev designet til det. Den dag droneproducenterne sætter sig ned og taler med de mennesker, der angiveligt skulle opnå bedre beskyttelse med dronerne hængende over hovedet, kunne markere begyndelsen på et ganske anderledes og sandt humanitært instrument. Men den dag er ikke oprunden, og det er tænkeligt, at Satan suser på skøjter til arbejde inden da.

Jeg tilskrev indledningsvis Seneca, at et sværd aldrig dræber nogen. Seneca var en vis mand, og det var næppe en opfattelse, han selv delte. Han rapporterede blot opfattelsen hos "visse mænd". Der er et andet citat, som sandsynligvis ligger tættere på hans eget synspunkt: "Våben overholder ingen grænser; ej heller lader sværdets vrede sig let tøjle eller tilfredsstille, når det først er trukket; krig svælger i blod."6

* Tak til to anonyme reviewere på Politik, som har reddet mig fra en del uklarheder og misforståelser, i særdeleshed vedrørende krigens love.

\section{Litteratur}

Ackerman, S. (2016). US to continue 'signature strikes' on people suspected of terrorist links. The Guardian. Tilgængelig på: https://www.theguardian.com/usnews/2016/jul/01/obama-continue-signature-strikes-drones-civilian-deaths

Arkin, R. (2010). The Case for Ethical Autonomy in Unmanned Systems. Journal of Military Ethics, årg. 9, s. 332-41.

\footnotetext{
${ }^{6}$ I: Den rasende Hercules, linje 403-05; egen, uautoriserede overs.
} 
Blank, L.R. (2012). Targeted Strikes: The Consequences of Blurring the Armed Conflict and Self-Defense Justifications. William Mitchell Law Review, årg. 38, s. $1655-1700$.

Boyle, M.J. (2015). The legal and ethical implications of drone warfare. The International Journal of Human Rights 19, s. 105-26.

Braun, M. \& Brunstetter, D.R. (2013). Rethinking the Criterion for Assessing CIA-targeted Killings: Drones, Proportionality and Jus Ad Vim. Journal of Military Ethics, årg. 12, s. 304-324.

Brooks, R. (2014). Drones and the International Rule of Law. Ethics \& International Affairs, årg. 28, s. 83-103.

Buchanan, A. \& Keohane, R. (2015). Toward a Drone Accountability Regime. Ethics \& International Affairs, årg. 29, s. 15-37.

Carrol, R. (2012). The philosopher making the moral case for US drones. Tilgængelig på: https://www.theguardian.com/world/2012/aug/02/philosopher-moral-case-drones.

Chamayou, G. (2015). Drone Theory. London: Penguin Books.

Cloud, D.S. (2011). Anatomy of an Afghan War Tragedy. Los Angeles Times. Tilgængelig på: http://articles.latimes.com/2011/apr/10/world/la-fg-afghanistan-drone20110410

Hallgarth, M.W. (2013). Just War Theory and Remote Military Technology: A Primer. I: B.J. Strawser (red.). Killing by Remote Control: The Ethics of an Unmanned Military. N.Y., Oxford UP.

Henriksen, A. \& Ringsmose, J. (2017). Slagmarkens moral og risikofri krig med droner. Politik, årg. 20(1), s. 12-20.

ICJ (International Court of Justice) (1996). Legality of the Threat or Use of Nuclear Weapons. Tilgængelig på: http://www.icj-cij.org/files/case-related/95/09519960708-ADV-01-00-EN.pdf

International Human Rights and Conflict Resolution Clinic (Stanford Law School) \& Global Justice Clinic (NYU School of Law) (2012). Living Under Drones: Death, Injury, and Trauma to Civilians from US Drone Practices in Pakistan. Tilgængelig på: http://chrgj.org/wp-content/uploads/2012/10/Living-Under-Drones.pdf.

Kahn, P. (2002). The Paradox of Riskless Warfare. Philosophy and Public Policy Quarterly, 22(3), s. 2-8.

Kilkullen D. \& Exum A. (2009). Death from Above, Outrage Down Below New York Times, 16. maj 2009. Tilgængelig på: http://www.nytimes.com/2009/05/17/opinion/17exum.html

Kretzmer, D. (2005). Targeted Killing of Suspected Terrorists: Extra-Judicial Executions or Legitimate Means of Defence? The European Journal of International Law, årg. 16, s. 171-212.

Matulich, D. (2012). Why COIN Principles Don't Fly with Drones. Small Wars Journal, årg. 24, 24. february 2012. Tilgængelig på: http://smallwarsjournal.com/jrnl/art/why-coin-principles-dont-fly-with-drones 
Mayer, J. (2015). The Predator War. I: M. Cohn (red.). Drones and Targeted Killing: Legal, Moral and Geopolotical Issues, MA: Olive Branch Press, s. 63-76.

McMahan, J. (2009). Killing in War. Oxford: Oxford UP.

McMahan, J. (2012). Targeted Killing: Murder, Combat, or Law Enforcement? I: C. Finkelstein et al. (red.), Targeted Killings: Law and Morality in an Asymmetric World. Oxford: Oxford UP.

Plaw, A. (2013). Counting the Dead: The Proportionality of Predation in Pakistan. I: BJ Strawser (ed.), Killing by Remote Control: The Ethics of an Unmanned Military. N.Y.: Oxford UP.

Rosén, F. (2013). Extremely Stealthy and Incredibly Close: Drones, Control, and Legal Responsibility. Copenhagen: DIIS Working Paper 2013: 04. Tilgængelig på: http://pure.diis.dk/ws/files/40139/WP2013_04_frro_Extremely_Stealthy.pdf.

Schwebel, S.M. (1996). International Court of Justice advisory opinion on the Legality of the Threat or Use of Nuclear Weapons: Dissenting Opinion of Vice-President Schwebel. Tilgængelig på: http://www.icj-cij.org/files/case-related/95/09519960708-ADV-01-09-EN.pdf.

Singer, P.W. (2010). The Ethics of Killer Applications. Journal of Military Ethics. årg. 9, s. 299-312.

Sparrow, R. (2009). Predators or plowshares? arms control of robotic warfare. IEEE technology and society Magazine, årg. 28, s. 25-29.

Steinhoff, U. (2013). Killing Them Safely: Extreme Asymmetry and Its Discontents. I: B.J. Strawser (red.). Killing by Remote Control: The Ethics of an Unmanned Military. N.Y.: Oxford UP.

Strawser, B.J. (2010). Moral Predators: The Duty to Employ Uninhabited Aerial Vehicles. Journal of Military Ethics, årg. 9, s. 342-68.

Strawser, B.J. (2012). The Morality of Drone Warfare Revisited. The Guardian. Tilgængelig på: https://www.theguardian.com/commentisfree/2012/aug/06/moralitydrone-warfare-revisited.

Strawser, B.J. (2013). Introduction: The Moral Landscape of Unmanned Weapons. I: B.J. Strawser (red.). Killing by Remote Control: The Ethics of an Unmanned Military. N.Y.: Oxford UP.

Waldron, J. (2012). Justifying Targeted Killing with a Neutral Principle? I: C. Finkelstein et al. (red.). Targeted Killings: Law and Morality in an Asymmetric World. Oxford: Oxford UP.

Whetham, D. (2015). Drones to protect', The International Journal of Human Rights, årg. 19, s. 199-210. 